\title{
POLITICAL VIDEO BLOGGING AS SOCIO-POLITICAL INTERNET BEHAVIOR
}

\author{
Myshok Romana ${ }^{1}$ \\ Lviv Polytechnic National University, Lviv, Ukraine \\ ${ }^{1} \mathrm{PhD}$ student in the Department of Sociology and Social Work
}

Background: According to the results of the Factum Group Ukraine research in 2019, in Ukraine the number of regular internet users compared to 2018 increased by $8 \%$ and accounted for $71 \%$ of the population. The core of the internet audience remains the youth, however, there is an increasing involvement of the population aged 50 years and more (Factum Group Ukraine, 2019). In this regard, the Internet is increasingly being used in different spheres of human activity: consumerism, work, leisure, entertainment and other. The significant role of the Internet can be observed in the process of Ukrainian state-building and civil society formation. Instant spreading of information with help of modern information and communication technologies, its accessibility allows to keep people aware of events, and the introduction of e-government promotes enhance the activity of the population. Such activity consists not only traditional forms of civic behavior and also in socio-political internet behavior, which encompasses a wide variety of social practices, including video blogging.

Purpose: To interpret the concept of political video blogging in the context of socio-political internet behavior.

Method: Methods were used: analysis for detailed acquaintance with the works of scientists in the chosen subject; synthesis for determining the essence and structure of the concept of political video blog, features of its typology.

Results: After analysis of scientific works revealed that the political video blogging has the characteristics and functions inherent in socio-political internet behavior. Firstly, video blogger activity is not concentrated only on the internet, which is characteristic of socio-political internet activity. This behavior has some influence (and not always positive) on solving of socio-political problems. Secondly, for viewers, the political video blog is a source of information and a medium for interacting with the video blogger or other users.

Conclusion: Political video blogging has been found to be a genre-themed type of blogging that has the characteristics of socio-political internet activity. It is revealed that political video blogging is not a popular type of video blogging in Ukraine.

Keywords: blog, video blog, political video blogging, socio-political internet behavior

Розглядати поняття відеоблогу неможливо без інтерпретації терміну «блог». Кандидат соціологічних наук О. Козаченко визначає блог як персональну веб-сторінка у формі особистого щоденника, яка містить замітки та новини, що регулярно поновлюються та $\epsilon$ доступними для коментарів інших користувачів. Крім цього, соціологиня розглядає блог як одну із форм інтернет-активності, а блогерів - «лідерами думок», які беруть активну участь у формуванні громадянського суспільства (Козаченко, 2013, с. 42). Зрозуміло, що відеоблог залишається «особистим щоденником» автора для публічного перегляду, тільки за допомогою іншого формату подачі інформації.

Російська соціологиня Е. Абросімова розглядає відеоблог як спосіб передачі візуальної інформації, що $є$ найбільш привабливим і затребуваним засобом комунікації в сучасному суспільстві. Структура відеоблогу, за їі словами, представлена трьома основними елементами: засоби докомунікативної презентації (тематика, назва, оформлення) безпосередньо відеоконтент і коментарі глядачів. Використовуючи соціометричний підхід до вивчення відеоблогу, Е. Абросімова отримала інформацію про процеси функціонування, розвитку груп, а також нові знання про соціальну організації сучасного суспільства. Відтак функціями відеоблогів є: найбільш важлива - комунікативна, далі в порядку значимості функції самопрезентації, розваги, згуртування і підтримки соціальних зв'язків, функція мемуарів і психотерапевтична. 
При визначенні функцій відеоблогінга як процесу відзначаються дві основні позиції користувача-актора: 1) глядач відеоблогів і 2) його автор. Люди, які не ведуть свій відеоблог i $\epsilon$ тільки глядачами, в основному використовують відеоблогосферу для організації спілкування 3 людьми. Крім функції підтримки контакту 3 іншими людьми глядач відеоблогів вирішує завдання отримання інформації; розваги; відстеження реакції публіки на ті чи інші дії авторів відеоблогів, перегляду відео заради соціалізації, відчуття себе причетним до життя відомих людей (Абросимова, 2018, с. 28-29).

Формати відеоблогів постійно трансформуються, розвиваються, з'являються нові напрямки, тому сьогодні не існує будь-якої офіційної класифікації. Науковці виділяють лише жанрово-тематичну спрямованість і на іï основі виділяють такі типи відеоблогів: огляд (розгляд одного або декількох об'єктів), летсплей (зйомка процесу проходження відеоігри), пранк (розіграш), челлендж (виконання мережевих завдань і заклик до його повтору), скетч (комедійна замальовка), б'юті-блоги, лайфхаки, блог мандрівника i політичний відеоблог. За функціональним призначенням розділяють інформаційні, розважальні та навчальні відеоблоги (Текутьева, 2016, с. 108).

Потрібно також закцентувати увагу на способі трансляції відеоблогів. Такі можливості надають різноманітні соціальні мережі та веб-сайти, найпопулярнішим серед яких $\epsilon$ YouTube відеохостингова компанія, що надає користувачам послуги зберігання, доставки та показу відео. Завдяки простоті і зручності використання YouTube став одним із найпопулярніших місць для розміщення відеофайлів і другим сайтом у світі за кількості відвідувачів. Відеоблогерів, які зосереджують свою роботу переважно в YouTube називають «ютуберами».

Серед названих типів відеоблогу саме політичний можна розглядати безпосередньо як форму соціально-політичної інтернет-поведінки.

Соціально-політична інтернет-поведінка - це окремий вид Інтернет-практик, діяльність людей, пов'язана 3 використанням сучасних Інтернет-технологій, задля регулювання суспільно-політичних проблем суспільства. Класифікувати цей вид соціальних практик можна виходячи з критерію рівня активності користувачів: активна поведінка, слактивізм та Інтернет-пасивність (Мишок, 2019). Проводячи багаторічні моніторинги перебування українських громадян в Інтернеті, соціологиня Н. Бойко умовно виділяє дві групи користувачів Інтернету (не визначаючи проміжний тип - слактивістів): активісти та нонактивісти. До першої вона відносить тих респондентів, які використовують Інтернет задля реалізації таких форм діяльності: отримання соціально-політичної інформації, формальна та неформальна онлайн взаємодія 3 державними органами, недержавними та міжнародними організаціями (е-послуги, е-запити тощо), неформальне спілкування в мережі 3 питань громадянсько-політичної проблематики; пошук однодумців, ініціювання та підтримка соціально-громадянських заходів, ініційованих онлайн; суспільний контроль за діяльністю державних установ, чиновників та посадовців (е-звіти, е-бюджет тощо) (Бойко, 2018 , с. 63). Важливо до цього додати, що результати активної діяльність в Інтернеті можна побачити в реальному житті (наприклад, здійснення користувачем реальної поведінки відвідування мітингів, голосування тощо). Така поведінка має визначені впливи на суспільство. Слактивізм ж означає певну діяльність особистості, повністю зосереджену в Інтернеті, таку, яка не має помітних наслідків у соціально-політичному житті країни. Результатом здійснення такої Інтернет-поведінки може бути формування у користувача ілюзорної причетності до процесів, що відбуваються в державі. До цього виду громадянської Інтернет-поведінки відносимо, наприклад, такі види діяльності, як підписка на певні групи у соціальних мережах, вподобання сторінок, світлин, поширювання постів тощо (Мишок, 2019). До нонактивістів або ж пасивних Інтернет-користувачів відносяться ті, хто не реалізовує жодної з перелічених форм поведінки.

Синтез понять відеоблогу та соціально-політичної інтернет-поведінки дозволяє інтерпретувати політичний відеоблогінг як онлайн ваємодію блогера, що публічно представляє відео, яке відображає його думки і судження з приводу соціально-політичних процесів в країні, 3 іншими користувачами інтернету. Зворотній зв'язок при цьому відбувається способом коментування користувачами цього відео, в результаті чого реалізується основна функція 
відеоблогу - комуннікативна. Онлайн-активність та імідж відеоблогерів, якість контенту відображається в кількості підписників, що позначає функцію згуртованості та підтримки соціальних зв'язків. Володіючи в реальному житті певним статусом та створивши собі відповідний імідж, відеоблогери стають лідерами думок для наявної аудиторії.

Враховуючи користувачів-акторів онлайн взаємодії, політичний відеоблогінг можна розглядати $з$ двох боків: по-перше, як активну соціально-політичну інтернет-поведінку автора відеоблогу, оскільки він реалізує поведінку і поза інтернетом (наприклад, для аргументації контенту проводить розлідування, аналіз документів, планування зустрічей з гостями відеоблогу тощо) та має на меті отримати певний результат від своєї активності - вплинути на думку аудиторії; по-друге, як джерело інформації для користувачів-підписників чи випадкових глядачів, які, в залежності від мети перебування в інтернеті та сприйняття інформації, проявляють або слактивізм (підписка заради підписки), або активність (систематичний перегляд відеоблогів зі зворотнім зв'язком). Свобода вибору джерела інформації в інтернеті робить відеоблог не тільки популярним способом отримання новин, але й створює небезпеку потрапляння під маніпулятивний вплив недобросовісних відеоблогерів, продукти діяльності яких можуть бути хоч i дуже привабливими, оригінальним та доступним, проте не підтвердженими або аргументованими фейковими фактами. Зважаючи на те, що кількість переглядів на платформі YouTube монетизується, нерідко відеоблогери звертаються до найрізноманітніших форм привернення уваги користувачів, наприклад клікбейту (англ. clickbait, від click - клацання i bait - наживка) гіперболізації та маніпулювання інформацією у заголовку відеоматеріалу, що шкодить якості або точності інформації в цілому (Лук'яненко, 2020).

В Україні політичний відеоблог порівняно з іншими типами відеоблогу не користується великою популярністю. Серед український користувачів та ютуберів найбільш популярними $\epsilon$ відеоблоги розважального характеру (огляди, летсплеї) та лайфхаки. В основному політичний відеоблог використовуються для організації політичної реклами. Таку технологію у своїй передвиборчій кампанії активно застосовував теперішній президент України В. Зеленський. Якщо не враховувати політичну рекламу, найвища активність політичних відеоблогерів проявляється саме на період виборів чи в ситуації кризи в країні. Відтак тематика сучасних українських політичних відеоблогів переважно зосереджується на війні на Сході України або на аналізі діяльності влади в країні.

Одними 3 найпопулярніших представників українського політичного відеоблогінгу на платформі YouTube можна назвати: Анатолія Шарія (2,33 млн. підписників, більше 3 млрд. переглядів), Дмитра Гордона (два основні канали сумарно 1 мільйон 843 тисячі підписників, більше 800 мільйонів переглядів), «Телебачення Торонто» (361 тисячі підписників, більше 71 мільйонів переглядів), Яніни Соколової (два основні канали сумарно 500 тисяч підписників, більше 40 мільйонів переглядів), «Андрей Луганський» (три основні канали сумарно 296 тисяч підписників, більше 67 мільйони переглядів). Специфіка передачі інформації у названих політичних відеоблогах різна (шоу, інтерв'ю, монолог), проте основна мета однакова - донесення аудиторії, розгляд та аналіз актуальних соціально-політичних проблем українського суспільства.

\section{References}

Factum Group Ukraine (2019). UIA Internet audience in Ukraine in 2019Q3 URL: https://www.slideshare.net/memabox/uia-internet-audience-in-ukraine-in-2019q3?fbclid=IwAR2 pA3p8b_mnMaizbqWwof2I8Z2N1vTMaC4KJX3y_XOhllZFxIxJruj-JM0 (date of request: 06.04.2020).

Abrosimova, E. E. (2018) Children's segment of the videoblogosphere: structure, functions and influence on socialization. PhD dissertation (Sociology). National Research Nizhny Novgorod State University N.I. Lobachevsky, Nizhny Novgorod. 
Boyko, N. L.(2018). Civic activity online: to a sociological portrait of a Ukrainian Internet user. Visnyk of the National Technical University of Ukraine "Igor Sikorsky Kyiv Polytechnic Institute”. Politology. Sociology. Law, Volume 1 (37), 61-65.

Kozachenko, O. O. (2013). Socio-demographic profile of the modern Ukrainian blogger (on the example of Correspondent. net and Ukrainian Pravda. Ukrainian Society, 2, 41-50.

Lukianyuk, V. (2020) Dictionary of foreign words URL: https:/www.jnsm.com.ua/cgi$\mathrm{bin} / \mathrm{u} /$ book/sis.pl? Article=9633\&action=show (date of request: 06.04.2020).

Myshok, R. R. (2019) Civil Internet behaviour of the Lviv student youth: the attempt of determination and classification. Visnyk of the National Technical University of Ukraine "Igor Sikorsky Kyiv Polytechnic Institute”. Politology. Sociology. Law, Volume 3 (43), 104-110.

Tekut'eva, I. A. (2016). Genre-thematic classification of video blogging. MediaEnvironment, (11), 107-113.

\section{Список використаних джерел}

Factum Group Ukraine (2019). UIA Internet audience in Ukraine in 2019Q3 URL: https://www.slideshare.net/memabox/uia-internet-audience-in-ukraine-in-2019q3?fbclid=IwAR2 pA3p8b_mnMaizbqWwof2I8Z2N1vTMaC4KJX3y_XOhllZFxIxJruj-JM0 (дата звернення: 06.04.2020).

Абросимова, Е. Е. (2018) Детский сегмент видеоблогосферы: структура, функции и влияние на социализацию (Диссертация на соискание ученой степени кандидата социологических наук) Национальный исследовательский Нижегородский государственный университет им. Н.И. Лобачевского, Нижний Новгород.

Бойко, Н. Л. (2018). Громадянська активність онлайн: до соціологічного портрету українського користувача інтернету. Вісник Національного технічного університету України «Киїський політехнічний інститут». Політологія. Соціологія. Право. Вип. 1 (37), 61-65.

Козаченко, О. О. (2013). Соціально-демографічний профіль сучасного українського блогера (на прикладі інтернет-видань Кореспондент. net та Українська правда. Український Сойум, 2, 41-50.

Лук'янюк, В. (2020) Словник іншомовних слів URL: https://www.jnsm.com.ua/cgibin/u/book/sis.pl?Article=9633\&action=show (дата звернення: 06.04.2020).

Мишок, Р. Р. (2019). Громадянська інтернет-поведінка львівської студентської молоді: спроба визначення і класифікації. Вісник Національного технічного університету Украӥни «Київський політехнічний інститут ім. І. Сікорського». Політологія. Соиіологія. Право, Bun.3 (43), 104-110.

Текутьева, И. А. (2016). Жанрово-тематическая классификация видеоблогинга. Медиасреда, (11), 107-113.

\section{Contact information:}

Romana Myshok romanamyshok@ukr.net 